\title{
Bee Honey as a Potentially Effective Treatment for Depression: A Review of Clinical and Preclinical Findings
}

\author{
Amira Mohammed Ali ${ }^{1 *}$ and Amin Omar Hendawy ${ }^{2}$ \\ ${ }^{1}$ Department of Psychiatric Nursing and Mental Health, Alexandria University, Alexandria, Egypt \\ ${ }^{2}$ Department of Poultry and Animal Production, Tokyo University of Agriculture and Technology
}

Submission: August 31, 2018; Published: September 10, 2018

*Corresponding author: Amira Mohammed Ali, Department of Psychiatric Nursing and Mental Health, Faculty of Nursing, Alexandria University, Edmon Fremon St, Smouha, Alexandria, 36741, Egypt, Tel: +203-4291-578; Email: mercy.ofheaven2000@gmail.com

\begin{abstract}
Failure of the antidepressant drugs to produce complete recovery in addition to their debilitating side effects forced researchers to find more acceptable and effective natural alternatives. Bee honey has exhibited several therapeutic benefits in physical health related problems; however, it is not clear if bee honey can have similar benefits for mental health problems. This paper systematically investigated the therapeutic effects of bee honey on depression. A search of PubMed resulted in 8 studies that assessed the effect of honey on depression (2 RCTs of human subjects and 6 animal studies). Findings support the therapeutic effectiveness of bee honey for improving biomarkers and symptoms of depression and anxiety. However, human studies had several methodological flaws and none of them assessed the biological effect of honey on depression. Therefore, more rigorous RCTs that compare the effect of different types of honey and its ingredient on specific biological and psychological measures of depression are needed.
\end{abstract}

Keywords: Alternative therapies; Complementary therapy; Depression; Honey; Mental disorders; Nutritional supplement; Therapeutic diet

\section{Introduction}

Depression is one of the most prevalent and recurrent mental disorders, which predominates among people with other psychiatric and physical disorders (e.g., diabetes, cancer, ETC) $[1,2]$. Affected individuals may be untreated for years [3]. Further, some would seek treatment but drop out because of the high cost, the limited effectiveness, and the debilitating side effects of the antidepressant drugs [4]. Depression severely impedes individuals' functioning and negatively affects their quality of life [5]. The community suffers further premature life loss because of the high incidence of suicideamong depressed people [1]. Research has recently implicated a link between a set of pathways in the pathophysiology of depression [6]. The gut michrobiome brain axis is a channel of communication between the brain and the gut. It involves hormonal, neuronal, and immune signals. Microflora naturally existing in the colon can cause mental disorders if they get access to the circulation. Evidence indicates that in particular lipopolysaccharide (LPS)-a component of cell walls of Gramnegative bacteria-has a high contribution to the occurrence of depression [7]. An intact gut lining prohibits passage of gut flora to the circulation. However, the stress diathesis model of depression indicates that depressed individuals respond to stressors by a series of physiological reactions that finally lead to inflammation-a process marked by cytokine release. Inflammation in turn cause collapse of the intestinal epithelial tight junctions and enhance intestinal permeability which cause translocation of the normally existing gut microflora to the circulation [8]. Research implicates that microflora translocation is associated with oxidative and nitrosative stress-another pathway of depression. Evidence indicates that gut-microbiota diet interactions play a significant role in major depression [6]. Accordingly, the last two decades witnessed a new trend where natural nutrients and diet can be used to cure mental problems.

Bee honey is a natural sweetener that is widely available across the world [9]. Human use of honey is traced to some 8000 years ago as depicted by Stone Age paintings. It has been used both as food and medicine since ancient times [10]. The therapeutic benefits of honey were mentioned a long time ago in both the Bible and Al Quran [11]. Honey has been used recently for the treatment of several gastrointestinal, cardiovascular, inflammatory and neoplastic states [10]. The literature indicates that bee honey can be beneficial for people with psychiatric and mental health problems $[12,13]$. Honey exhibits strong antioxidant properties stress since it is rich with a wide range of compounds including phenolics, peptides, organic acids, enzymes, and Maillard reaction products. Honey is reported to exert an inhibitory effect on around 60 species of bacteria, some species of fungi and viruses [10]. Therefore, honey can counteract oxidative stress and positively affect the gut microflora in depressed patients. Honey can have a nootropic effect (e.g., memory-enhancement) and neuropharmacological effects e.g., 
alleviating anxiety and depressive symptoms [12]. However, research in this area is still in the womb; a relatively limited number of studies-which mainly involve animal subjects-reported psychotropic benefits of honey [14-18]. Nonetheless, it is worthy to systematically explore the therapeutic effects of bee honey on symptoms and biomarkers of depression. The hypothesis of this study is that people with depression symptoms who receive bee honey exhibit less symptoms at posttreatment compared with control groups.

\section{Methods}

\section{Database Search}

A search of PubMed databases was conducted in December 2017 using a combination of keywords of honey and depression terms (see supplement 1 for detailed search strategy). No constrains were applied to limit the search. Eligible studies were: 1) experimental trials that used bee honey as a primary or adjunctive intervention for depression or anxiety, 2) involving human or animal subjects in any setting 3) reporting outcomes of symptoms change or biological markers of depression or anxiety. The primary outcomes were depressive symptoms and biomarkers of depression. Reported secondary outcomes in the reviewed studies were also considered.

\section{Data Extraction}

The following data extract were extracted from the selected studies:

a) study characteristics (aims, design, setting, participants' characteristics, randomization procedures, inclusion and exclusion criteria, etc.),

b) outcome measures (instruments, measurement points, attrition, etc.),

c) honey supplementation procedures (dose amount, number of doses, duration of treatment, frequency of administration, combination with other supplements, etc.), and

d) study results (significant effects, sustainability, etc.).
Data on the methodological quality of the reviewed studies were also collected e.g., method of randomization, allocation concealment, blinding of participants and researcher to the study hypotheses as well as percentage of attrition and reasons for attrition.

\section{Results}

\section{Outcome of Literature Search}

The database search resulted in 74 articles. Only two studies involved human subjects while 6 studies involved animal subjects and all were included in this review. It was first decided that studies to be included should only include human subjects. However, studies with human subjects were limited, meanwhile a considerable number of studies that included animal subjects reported valuable information, which can back-bone the findings from human participants.

\section{Quality of the Reviewed Studies}

Although both studies used a randomized control design, the method of randomization was not revealed in any of the studies. Neither of them described if allocation concealment procedures were used, and thus were rated high risk for selection bias. It was not also indicated whether participants and researchers were blinded to the study hypotheses, and thus were rated high risk information and reporting bias. In one study attrition rate was 16.66\% (6 participants) and reasons for attrition were reported, and thus was rated low risk for attrition bias [19]. Despite the fact that reasons for attrition were reported in the second study, this study was rated high risk for attrition bias since 32.6\% (15 participants) dropped from the second phase of the trial [13]. The latter study also reported high on other biases such as not describing inclusion criteria and procedure of sample size estimation. Concerning the reviewed animal studies, most of the studies reported use of randomization; however, the method was not indicated. Blinding of the observer was noted in one study [15]. Whenever available we included data about the included animals such as numbers, gender, age, weight, genetic line, and the like. In few instances viable data such as the dose or the duration of treatment were not reported [20]. Missing data are indicated as not reported.

Table 1: Sociodemographic and clinical characteristics of participants of the included human trials $(\mathrm{N}=2)$.

\begin{tabular}{|c|c|c|c|c|c|c|c|}
\hline Study and sample & Country & Mage (years) & Race & Education & Gender & $\begin{array}{c}\text { Other } \\
\text { treatments }\end{array}$ & Co-morbidity \\
\hline $\begin{array}{c}\text { Badrasawi et al. [19] } \\
(\mathrm{N}=36)\end{array}$ & Malaysia & $66.8 \pm \mathrm{NR}$ & $76.7 \%$ Malays & $\begin{array}{c}65.5 \% \text { had } 6 \text { years } \\
\text { of education }\end{array}$ & $30 \%$ females & NR & $40 \%$ obese \\
\hline $\begin{array}{c}\text { Münstedt et al. [16] } \\
(\mathrm{N}=46)\end{array}$ & Turkey & $60.8 \pm 11.2$ & $\mathrm{NR}$ & $\mathrm{NR}$ & $100 \%$ females & $\begin{array}{c}\text { Hormonal } \\
\text { therapy }\end{array}$ & Cancer \\
\hline
\end{tabular}

NR: Not reported

\section{Characteristics of the Included Studies}

Screening of the obtained publications resulted in inclusion of two human studies in this review. Included studies comprised 82 participants in total, and the design used was an RCT crossover design with a wash out period that ranged between one and two weeks. Sociodemographic and clinical characteristics of samples included are shown in Table 1. Participants in both studies were elderly, and the majority was females. Please check Table 3 for characteristics of the included animals. Table 2 shows that treatment with honey took place over the course of 2-3 weeks. 
In one study honey was combined with milk and barely powderthis mix is called Talbinah-the exact dose of honey was not clear. Meanwhile in the other study a tablespoon of honey was given every morning. Four main indices were used to measure the effect of honey on psychological symptoms namely: Geriatric Depression
Scale (GDS-R), Depression Anxiety Stress Scales (DASS), Profile of Mood States (POMS), Menopause Rating Scale (MRS). Other related secondary outcomes were also targeted-nutritional status and dietary intake, total cholesterol, HDL, or LDL, triglycerides, oestradiol.

Table 2: Characteristics of the included human trials $(\mathrm{N}=2)$.

\begin{tabular}{|c|c|c|c|}
\hline Study & Task & Measures and follow up & Results \\
\hline $\begin{array}{l}\text { Badrasawi } \\
\text { et al. [19] }\end{array}$ & $\begin{array}{l}\text { EG: }(n=18) \text { usual diet and one daily } \\
\text { serving of Talbinah/3 weeks }\end{array}$ & P: GDS-R, DASS, and POMS & $\begin{array}{l}\text { A statistically significant decrease on depression, stress, and mood } \\
\text { disturbances scores in the EG compared with the CG }(p<0.05) \text {. }\end{array}$ \\
\hline \multirow[t]{3}{*}{ RCT } & CG: $(n=18)$ usual diet & $\begin{array}{l}\text { S: Nutritional status and } \\
\quad \text { dietary intake }\end{array}$ & $\begin{array}{l}\text { A statistically significant improvement of dietary intake "calories, } \\
\text { zinc, and magnesium" in the EG compared with the CG }(p<0.05) \text {. }\end{array}$ \\
\hline & Dose of honey: NR & $\begin{array}{l}\text { Measurement: week } 0,3 \\
\quad 4 \text {, and } 7\end{array}$ & \\
\hline & Wash out period: 1 week & & \\
\hline Münstedt & EG: $(n=36)$ a pollen honey mixture & P: MRS & $\begin{array}{l}\text { Significant improvements in the MRS and its } 3 \text { subscales in the two } \\
\text { groups in a pre-post analysis (the between group difference was } \\
\text { non-significant). Participants noticed improvement 3-4 days after } \\
\text { the initiation of the study. }\end{array}$ \\
\hline \multirow[t]{3}{*}{ RCT } & CG: $(n=41)$ pure honey & $\begin{array}{l}\text { S: Total cholesterol, HDL, } \\
\text { or LDL, triglycerides, } \\
\text { oestradiol }\end{array}$ & $\begin{array}{l}\text { Significant improve }\urcorner \text { ment in the symptoms associated with the } \\
\text { antihormonal medication in the pure honey group. }\end{array}$ \\
\hline & $\begin{array}{l}\text { Dose of honey: Tablespoonful for } \\
14 \text { days }\end{array}$ & $\begin{array}{l}\text { Measurement: Pre and } \\
\text { posttreatment }\end{array}$ & $\begin{array}{c}\text { No pre to posttreatment differาences in the serum levels of } \\
\text { cholesterol (total, HDL, or LDL cholesterol), triglycerides or } \\
\text { oestradiol. }\end{array}$ \\
\hline & Wash out period: 2 weeks & & $\begin{array}{l}\text { On a } 10 \text {-point taste scale, }(1=\text { very good to } 10=\text { very bad }) \text {, honey } \\
\text { received an average score of } 2.3 \text {, whereas the pollen preparation } \\
\text { received an average score of } 6.0 .\end{array}$ \\
\hline
\end{tabular}

\section{Abbreviations}

RCT: randomized control trial, EG: experimental group, CG: control group, P: primary outcome measures, S: secondary outcome measures, NR: not reported, GDS-R: Geriatric Depression Scale, DASS: Depression Anxiety Stress Scales, POMS: Profile of Mood States, MRS: Menopause Rating Scale, HDL: High density lipoprotein, LDL: Low density lipoprotein.

Table 3: Characteristics of included pre-clinical trials (administration of bee honey in animals) $(\mathrm{N}=6)$.

\begin{tabular}{|c|c|c|c|}
\hline $\begin{array}{l}\text { Study and } \\
\text { sample }\end{array}$ & Task & Measures and follow up & Results \\
\hline $\begin{array}{l}\text { Abidin et al. } \\
\text { [16] } \\
\text { Malysia } \\
\text { Species: rats } \\
\text { (N=20) } \\
\text { Genetic line: } \\
\text { Sprague-Dawley } \\
\text { sp (SD) }\end{array}$ & $\begin{array}{c}\text { Chronic unpredictable mild stress } \\
\text { (CUMS) for 28-days } \\
\text { EG1: CG1: stress group (CUMS } \\
\text { only) } \\
\text { EG2: CUMS + Tualang honey } 1.2 \\
\text { mg/kg/day orally } \\
\text { EG3: CUMS + Acacia honey } 1.2 \mathrm{mg} / \\
\text { kg/day orally } \\
\text { CG: non-treatment unstressed rats }\end{array}$ & $\begin{array}{l}\text { Blood cortisol level } \\
\text { Heamolysis of erythrocytes } \\
\text { Weight change } \\
\text { Behavioral changes (open } \\
\text { field test) } \\
\text { Pre and posttreatment }\end{array}$ & $\begin{array}{l}\text { Rats in the stress group developed anhedonia behaviour on } \\
\text { the sucrose preference test at week- } 2(\mathrm{p}<0.01) \text { compared } \\
\text { to pre-treatment. } \\
\text { Significantly higher cortisol in stressed group }(1.62 \mathrm{ng} / \mathrm{mL} \text {, } \\
\mathrm{p}=0.012) \text { ) compared with the Acacia honey }(0.20 \mathrm{ng} / \mathrm{mL}) \\
\text { and the control group }(0.32 \mathrm{ng} / \mathrm{mL}) . \\
\text { Significantly lower percentage of erythrocytes haemolysis < } \\
50 \% \text { after } 180 \text { minutes in both Tualang and Acacia rats. } \\
\text { Significantly lower percentage of weight changes and } \\
\text { energy efficiency in Tualang rats }(15.69 \%, \mathrm{p}=0.007) \text { and } \\
\text { Acacia rats }(0.0029 \text { eef, } \mathrm{p}=0.021) \text { compared to the control } \\
\text { groups }(25.91 \%) \text { and }(0.0054 \text { eef }) \text { respectively. } \\
\text { Significantly higher open field test activities in Acacia honey } \\
\text { than in controlled and stress group. }\end{array}$ \\
\hline
\end{tabular}




\begin{tabular}{|c|c|c|c|}
\hline $\begin{array}{l}\text { Azman et al. } \\
\qquad[15] \\
\text { Malaysia } \\
\text { Species: adult } \\
\text { male rats } \\
\text { (N=48) } \\
\text { Genetic line: } \\
\text { Sprague-Dawley }\end{array}$ & $\begin{array}{c}\text { Rats were randomly divided into } \\
\text { 4 groups: } \\
\text { EG1:non-stressed } \\
\text { with Tualang honey } \\
\text { EG2: stressed with honey. } \\
\text { CG1: stressed with distilled water } \\
\text { CG2: non-stressed with distilled } \\
\text { water } \\
\text { Concentrated Tualang } 0.2 \mathrm{~g} / \mathrm{kg} \\
\text { body weight once daily for } 35 \text { days } \\
\text { via oral gavage. } \\
\text { On days 22-35, white noise for } 4 \mathrm{~h} \\
\text { was implemented. }\end{array}$ & $\begin{array}{l}\text { Novel object recognition } \\
\text { test to evaluate working } \\
\text { memory and the forced } \\
\text { swimming test to evaluate } \\
\text { depressive-like behaviour } \\
\text { (Climbing, swimming, being } \\
\text { motionless) } \\
\text { posttreatment between day } \\
36 \text { and } 41\end{array}$ & $\begin{array}{l}\text { Honey supplementation counteracted the intense } \\
\text { cognitive dysfunction induced by noise stress evidenced by } \\
\text { significant effects of honey on short and long-term memory } \\
{[\mathrm{F}(1,46=18.45, \mathrm{P}<0.01] \text { and }[\mathrm{F}(1,46=34.7, \mathrm{P}<0.01] \text {, }} \\
\text { respectively. } \\
\text { Significant increase of durations of climbing }[\mathrm{F}(1,43= \\
6.27, \mathrm{P}<0.01] \text { and swimming }[\mathrm{F}(1,43=11.32, \mathrm{P}<0.01] \\
\text { and decrease of immobility }[\mathrm{F}(1,45=19.65, \mathrm{P}<0.01] \text { in } \\
\text { honey-supplemented rats demonstrate antidepressant-like } \\
\text { effects. }\end{array}$ \\
\hline $\begin{array}{l}\text { Al Rahbi et al } \\
\quad[14] \\
\text { Malaysia } \\
\text { Species: adult } \\
\text { female rats } \\
\quad(\mathrm{N}=60) \\
\text { Genetic line: } \\
\text { Sprague-Dawley } \\
\text { Age= } 8 \text { weeks } \\
\text { Mean body } \\
\text { weight= } 200 \pm \\
20 \mathrm{~g}\end{array}$ & $\begin{array}{l}\text { Social stress: alternate isolation } \\
\text { and crowding phases for } 24 \text { hrs } \\
\text { over } 15 \text { days. } \\
\text { Rats were randomly divided into } \\
5 \text { groups: } \\
\text { (i) nonstressed sham-operated } \\
\text { control rats; (ii) sham-operated } \\
\text { control rats exposed to stress; (iii) } \\
\text { nonstressed and OVX rats; (iv) OVX } \\
\text { rats exposed to stress; (v) OVX } \\
\text { rats exposed to stress and treated } \\
\text { with } 17 \beta \text {-E2 ( } 20 \text { ug daily, sc), and } \\
\text { (vi) OVX rats exposed to stress and } \\
\text { treated with Tualang honey (0.2 g/ } \\
\text { kg body weight, orally). } \\
\text { Treatments started } 3 \text { days prior to } \\
\text { stress procedures and continued } \\
\text { throughout the } 15 \text { days of stress } \\
\text { procedures. }\end{array}$ & $\begin{array}{l}\text { Oxidant/antioxidant status } \\
\text { of the brain homogenates } \\
\text { (ELISA kits). } \\
\text { Serum oestradiol and } \\
\text { corticosterone levels. } \\
\text { open field test measured } \\
\text { anxiety-like behaviors:(i) } \\
\text { movement including rearing } \\
\text { events (number of vertical } \\
\text { activity), freezing time } \\
\text { (seconds), and grooming } \\
\text { time (seconds); (ii) } \\
\text { locomotive activity, that is, } \\
\text { time spent crossing the line } \\
\text { (seconds); (iii) autonomic } \\
\text { nervous system responses } \\
\text { including defaecation } \\
\text { (number of faecal boli) and } \\
\text { number of face-washing } \\
\text { events. }\end{array}$ & $\begin{array}{l}\text { Tualang honey-treated stressed OVX rats exhibited } \\
\text { significant reductions in ACTH, corticosterone levels, and } \\
\text { depressive-like behavior. They exhibited a significant } \\
\text { elevation in brain-derived neurotrophic factor (BDNF) } \\
\text { concentration. } \\
\text { Prolonged Tualang honey supplementation in stressed OVX } \\
\text { rats produced anxiolytic effects comparable to E2. } \\
\text { The levels of malondialdehyde (MDA) and protein carbonyl } \\
\text { (PCO) were significantly decreased while the levels/ } \\
\text { activities of superoxide dismutase (SOD), glutathione } \\
\text { S-transferases (GST), glutathione peroxidase (GPx), and } \\
\text { were significantly increased in the brain homogenates } \\
\text { of both E2 and Tualang treated stressed OVX groups } \\
\text { compared with untreated stressed OVX. }\end{array}$ \\
\hline $\begin{array}{l}\text { Chepulis et al. } \\
\text { [17] } \\
\text { Species= adult } \\
\text { rats } \\
\quad(\mathrm{N}=45) \\
\text { Genetic line: } \\
\text { Sprague-Dawley } \\
\text { Age= } 8 \text { weeks }\end{array}$ & $\begin{array}{l}\text { Rats were fed ad libitum for } 52 \\
\text { weeks } \\
\text { CG1:sugar-free powdered diet that } \\
\text { was either sugar-free } \\
\text { CG2:powdered diet plus } 7.9 \% \\
\text { sucrose } \\
\text { EG: powdered diet plus 10\% honey }\end{array}$ & $\begin{array}{l}\text { Anxiety levels assessed by } \\
\quad \text { Elevated Plus Maze } \\
\text { Memory assessed by Y maze } \\
\text { and Object Recognition task } \\
\text { Locomotor activity assessed } \\
\text { by Open Field task } \\
\text { Posttreatment, 3, 6, } 9 \text { and } 12 \\
\text { months }\end{array}$ & $\begin{array}{c}\text { Significant reduction of anxiety and improvement of spatial } \\
\text { memory at all stages of ageing in honey-fed rats compared } \\
\text { with fed sucrose rats. } \\
\text { No significant group differences among groups the Object } \\
\text { Recognition task and locomotor activity at either } 6 \text { or } 12 \\
\text { months. }\end{array}$ \\
\hline $\begin{array}{l}\text { Oyekunle et al. } \\
\text { [18] } \\
\text { Nigeria } \\
\text { Species= adult } \\
\text { rats } \\
(\mathrm{N}=40) \\
\text { Genetic line: } \\
\text { Wistar rats } \\
\text { Age }=100 \text { to } \\
120 \mathrm{~g}\end{array}$ & $\begin{array}{c}\text { CG: usual diet } \\
\text { EG1: usual diet plus } 10 \% \text { aquatic } \\
\text { honey solution } \\
\text { EG2: usual diet10 plus } 20 \% \\
\text { aquatic honey solution } \\
\text { EG3: usual diet10 plus } 40 \% \\
\text { aquatic honey solution } \\
\text { Bee honey doses }(0.5,1.0, \\
\text { and } 2.0 \text { g/1 kg body weight). } \\
\text { Treatment involved a single dose. }\end{array}$ & $\begin{array}{l}\text { Anxiety levels assessed by } \\
\text { the hole-board (HB) } \\
\text { Locomotor activity assessed } \\
\text { by Open Field task } \\
1 \mathrm{hr} \text { afteposttreatment }\end{array}$ & $\begin{array}{l}\text { Among the doses tested, only higher ones induced } \\
\text { considerable changes in the behavioral indices. } \\
\text { The highest dose }(2.0 \mathrm{~g} / \mathrm{kg} \text { ) provided a more than twofold } \\
\text { increase in the number of examined holes in the HB test; } \\
\text { in the OF test, it also increased the numbers of crossed } \\
\text { squares, rearings, and grooming episodes by } 30,37 \text {, and } \\
164 \% \text {, respectively }\end{array}$ \\
\hline
\end{tabular}




\begin{tabular}{|c|c|c|c|}
\hline $\begin{array}{l}\text { Yildiz et al. [20] } \\
\text { Turkey and } \\
\text { (N= NR) } \\
\text { Genetic line: NR } \\
\text { Age: NR }\end{array}$ & $\begin{array}{l}\text { The study included In vivo and in } \\
\text { vitro experiments. } \\
\text { Aquatic honey, pollen and propolis } \\
\text { extracts were prepared in different } \\
\text { concentrations (NR). } \\
\text { Rat treatment doses and duration } \\
\text { were not reported }\end{array}$ & $\begin{array}{c}\text { Total phenolic contents } \\
\text { (TPC) and ferric reducing/ } \\
\text { antioxidant power (FRAP) } \\
\text { methods } \\
\text { Enzyme inhibition } \\
\text { MAO rat liver mitochondria } \\
\text { detected by photometric } \\
\text { assay }\end{array}$ & $\begin{array}{l}\text { Propolis had the highest TPC and antioxidant activity } \\
\text { followed by pollen, and honey. } \\
\text { Propolis, pollen and honey, in decreasing order, all inhibited } \\
\text { MAO enzyme activity } \\
\text { All effects were higher with increased concentrations. }\end{array}$ \\
\hline
\end{tabular}

Abbreviations:

EG: experimental group, CG: control group, NR: not reported, min: minutes, hr: hour.

\section{Therapeutic Effects of Honey}

Depressed elderly treated with a mix of honey and barely exhibited a significant decrease on depression, stress, and mood disturbances scores compared with the control group $(p<0.05)$. They also witnessed improvement of dietary intake "calories, zinc, and magnesium" ( $<$ 0.05) [19]. The second study revealed that treatment with honey or a mix of honey and pollens resulted in improvements of the three subscales of the Menopause Rating Scale (MRS) 68.3\% and 70.9\%, respectively. The reported improvement at posttreatment was significant than pretreatment in both groups with no between group differences. The symptoms associated with the antihormonal medication decreased with administration of honey. Meanwhile there were no pre to postreatment difference in serum levels of cholesterol (total, HDL, or LDL cholesterol), triglycerides or oestradiol in both groups [13].

\section{Participants' Feedback on Treatment with Honey}

Participants reported that they observed improvements 3-4 days after the initiation of the initiation of treatment. On a 10 -point taste scale ( $1=$ very good and $10=$ very bad $)$ honey received an average score of 2.3 , whereas a honey and pollen mix received an average score of 6.0. Nonetheless, minor side effects such as exhaustion and edema of lower extremities were reported in a limited number of participants [13]. The other study reported that two participants did not accept the taste of the mix of honey with barely powder [2].

\section{Characteristics of the Included Animal Studies}

The included animal studies used different animal species and different types of bee honey; duration of administration and doses also varied. Posttreatment and follow up varied greatly as well ( 1 hour to 12 months from initiation of treatment). While some studies used mild stress, others reported use of stress plus ovariectomy, while others did not report induction of any stress. Check Table 3 for further experimental details of the included animal studies.

\section{Therapeutic Effect of Honed Reported from Animal Studies}

All the included animal studies showed positive effect of honey on depression. Several studies reported improvement of depressive-like behaviors, cognitive function, and symptoms of anhedonia following consumption of bee honey [14-16]. In addition, honey supplementation to depressed rats showed similar improvement in biological markers of depression e.g., blood cortisol level and ACTH and markers of oxidative stress as well as heamolysis of erythrocytes [14,16]. Reduction of anxiety symptoms and improvement of spatial memory were also reported $[17,18]$. Solo administration of honey and other bee products such as propolis and pollen inhibited MAO enzyme activity in the liver of treated mice [20]. It is reported that greater improvements were noted with administration of high doses of honey $[17,18]$.

\section{Discussion}

To date there have been only two intervention studies in humans that assessed the beneficial effect of bee honey on depression and anxiety symptoms. Results of human trials indicate that honey-either administered alone or in combination with other bee products such as pollens or other plant compounds such as barely powder-can be a promising treatment for depressive and anxiety symptoms. Animal studies lend further support to the effectiveness of bee honey for depression since both depressive like behaviors and depression biomarkers were improved in all studies. Consumption of high doses of honey is likely to prevent and treat depression. However, generalizability of the findings is limited: response of animal models can differ from humans, and human studies were limited in number and quality. Furthermore, one study used a mixture of honey, cow milk, and barley powder, thus the effect cannot be attributed to honey alone [19]. Meanwhile, participants in the second study did not have a diagnosis of depression (menopausal women with mastectomy who underwent hormonal replacement therapy), and depressive symptoms were assessed by the Menopause Rating Scale (MRS)not as accurate as other specific measures e.g., Beck Depression Scale [13]. More, neither study measured any biological markers of depression. Further, it is not clear from the animal or human studies which ingredients of honey have the highest therapeutic properties.

\section{Strength and Limitations}

This study has the merit of being the first to systematically examine the effect of honey on depression. However, findings cannot be generalized since only two human studies were available for review and since participants were elderly people and menopausal cancer patients. The methodological quality of the involved studies has not been properly addressed. Despite 
the fact that PubMed is the most comprehensive database, lack of fund did not allow us to search other databases. The limited number of studies and heterogeneity of samples and measured prevented the possibility for met-analysis.

\section{Conclusion}

Bee honey can be a promising treatment for depression. However, more rigorous randomized control trials in humans are needed to confirm if honey can really alleviate depressive symptoms and improve its biomarkers. There is also a need to know which ingredients of honey have the most therapeutic effect.

\section{References}

1. Setoyama D, Kato TA, Hashimoto R, Kunugi H, Hattori K, et al. (2016) Plasma metabolites predict severity of depression and suicidal ideation in psychiatric patients-A multicenter pilot analysis. PloS one 11(12): e0165267.

2. Ali AM, Green J (2017) Differential item functioning of the arabic version of the depression anxiety stress scale-21 (dass-21). JOJ Nurse Health Care 4(5).

3. Ali AM, Ahmed A, Sharaf A, Kawakami N, Abdeldayem SM, et al (2017) The arabic version of the depression anxiety stress scale-21: Cumulative scaling and discriminant-validation testing. Asian J Psychiatr 30: 56-58.

4. Davis JM, Giakas WJ, Qu J, Prasad P, Leucht S (2011) Should we treat depression with drugs or psychological interventions? A reply to Ioannidis. Philos Ethics Humanit Med 6: 8.

5. Ali AM, Sharaf A, Abdeldayem SM, Kawakami N (2017) The effect of expressive disclosure writing on self-stigma, depression, and anxiety among drug users in a governmental hospital in Egypt: A nonrandomized controlled trial. J Depress Anxiety Disord 1(1): 31-40.

6. Slyepchenko A, Maes M, Jacka FN, Kohler CA, Barichello T, et al. (2017) Gut microbiota, bacterial translocation, and interactions with diet: Pathophysiological links between major depressive disorder and noncommunicable medical comorbidities. Psychother psychosom 86(1): $31-46$.

7. Subero MM, Anderson G, Kanchanatawan B, Berk M, Maes M (2016) Comorbidity between depression and inflammatory bowel disease explained by immune-inflammatory, oxidative, and nitrosative stress tryptophan catabolite; and gut-brain pathways. CNS Spectr 21(2): 184198
8. Kiecolt Glaser JK, Derry HM, Fagundes CP (2015) Inflammation: Depression fans the flames and feasts on the heat. Am J Psychiatry 172(11): 1075-1091.

9. Rao PV, Krishnan KT, Salleh N, Gan SH (2016) Biological and therapeutic effects of honey produced by honey bees and stingless bees: A comparative review. Revista Brasileira de Farmacognosia 26(5): 657-664.

10. Eteraf Oskouei T, Najafi M (2013) Traditional and modern uses of natural honey in human diseases: A review. Iran J Basic Med Sci 16(6): 731-742.

11. Oldroyd BP, Wongsiri S (2014) Asian honey bees: Biology, conservation, and human interactions.

12. Rahman MM, Gan SH, Khalil MI (2014) Neurological effects of honey: Current and future prospects. Evid Based Complement Alternat Med.

13. Munstedt K, Voss B, Kullmer U, Schneider U, Hubner J (2015) Bee pollen and honey for the alleviation of hot flushes and other menopausal symptoms in breast cancer patients. Mol Clin Oncol 3(4): 869-874.

14. Al Rahbi B, Zakaria R, Othman Z, Hassan A, Ahmad AH (2014) Protective effects of tualang honey against oxidative stress and anxiety-like behaviour in stressed ovariectomized rats. Int Sch Res Notices.

15. Azman KF, Zakaria R, AbdAziz C, Othman Z, Al Rahbi B (2015) Tualang honey improves memory performance and decreases depressive-like behavior in rats exposed to loud noise stress. Noise Health 17(75): 83 89.

16. Abidin QHZ, Rujhan NHM, Ismail WIW, Ismail NE, Eshak Z (2017) Potential used of Tualang and Acacia Honey in ameliorating stressdepression disorder: A preliminary study.

17. Chepulis LM, Starkey NJ, Waas JR, Molan PC (2009) The effects of longterm honey, sucrose or sugar-free diets on memory and anxiety in rats. Physiol Behav 97(3-4): 359-368.

18. Oyekunle OA, Ogundeji TP, Okojie AK (2011) Behavioral modifications related to consumption of a "soft" adaptogen, bee honey, by rats. Neurophysiology 43(1): 38-41

19. Badrasawi MM, Shahar S, Manaf ZA, Haron H (2013) Effect of Talbinah food consumption on depressive symptoms among elderly individuals in long term care facilities, randomized clinical trial. Clin Interv Aging 8: 279-285.

20. Yildiz O, Karahalil F, Can Z, Sahin H, Kolayli S (2014) Total monoamine oxidase (MAO) inhibition by chestnut honey, pollen and propolis. J Enzyme Inhib Med Chem 29(5): 690-694.

\section{Your next submission with Juniper Publishers will reach you the below assets}

- Quality Editorial service

- Swift Peer Review

- Reprints availability

- E-prints Service

- Manuscript Podcast for convenient understanding

- Global attainment for your research

- Manuscript accessibility in different formats

(Pdf, E-pub, Full Text, Audio)

- Unceasing customer service

Track the below URL for one-step submission https://juniperpublishers.com/online-submission.php 